\title{
A REVIEW OF COMMUNITY-BASED NATURAL RESOURCE MANAGEMENT
}

\author{
MILUPI, I. D. ${ }^{1,2^{*}}$ - SOMERS, M. J. ${ }^{1,3}-$ FERGUSON, W. ${ }^{2}$ \\ ${ }^{1}$ Centre for Wildlife Management, University of Pretoria, Pretoria, South Africa \\ ${ }^{2}$ Centre for Environmental Studies, University of Pretoria, Pretoria, South Africa \\ ${ }^{3}$ Centre for Invasion Biology, Mammal Research Institute, University of Pretoria \\ Pretoria, South Africa \\ *Corresponding author \\ e-mail: inongemilupi69@gmail.com
}

(Received $30^{\text {th }}$ Mar 2017; accepted $4^{\text {th }}$ Jul 2017)

\begin{abstract}
This paper reviews initiatives of Community-Based Natural Resource Management (CBNRM) from 21 case studies in different countries. The study uses Ostrom's design principles and eight objective measures. These are empowerment, public participation, equity, conflict resolution mechanisms, similarities between misuse and establishment of rules for indigenous environments, effective monitoring, collective choice arrangements and sanctioning activities for the use of common resources to evaluate and compare the case studies to examine the cases. Based on the analyses, successes and failures of CBNRM were determined. Successes were evident in the management of water resources in Honduras, India, Kenya, Nepal and St Lucia. CBNRM was also successful in Fiji, in joint forest management in India and other instances such as in Alaska, China, Cambodia, Namibia, Malaysia, Mexico, Washington, and to a small extent in Papua New Guinea. However, CBNRM initiatives failed in managing wildlife conservation in Nepal and Kenya, and in Tanzania wildlife management, Uganda and Zimbabwe. CBNRM failure was attributed to the uneven distribution of the benefits of natural resources, lack of empowerment, low community participation, failure to resolve conflicts, among many factors. In this study, the recommendations is made that similar research should be conducted with a larger sample size and employ other techniques such as Principal Component Analysis for examining the characteristics that achieve effective and sustainable CBNRM initiatives.
\end{abstract}

Keywords: community, participation, biodiversity, water management, sustainability, international comparison

\section{Introduction}

The worldwide failure of centralised approaches to managing natural resources led to the search for a viable and sustainable alternative approach by conservationists to achieve sustainable management (Nabane and Matzke, 1997). The approach whereby local communities are given ownership rights to manage natural resources became common in the 1960s when it was named community-based natural resource management (CBNRM). It is also called community-based conservation. According to Songorwa (1999), CBNRM aimed to create conditions under which most members of the community stood to benefit from the sustainable utilisation and management of wildlife resources. This would occur through a bottom-up participatory approach (Songorwa, 1999) based on a number of principles. These principles, which include meeting the basic needs of local people, putting resources under local control rather than the control of the state government, obtaining equal delivery and apportionment of socio-economic benefits and resources, and commitment involving members of the community and the local institutions in managing and conserving natural resources. This would be achieved regardless of their gender and would encompass the defence 
and legitimisation of local resources and property rights. There would also be a willingness to embrace traditional values and ecological knowledge in the management of present resources and a need to associate and resolve the objectives of social and economic growth for the protection and conservation of natural resources in the environment (Songorwa, 1999; Kellert et al., 2000). Also, CBNRM attempts to integrate the goals of conservation, sustainable development and community participation (UNDP, 2012c). This is performed by applying Ostrom's 1990 design principles (Table 1) on governing the common elements concerning empowerment, public participation, equity, conflict resolution mechanisms, congruence between appropriation and provision of rules for local conditions, effective monitoring, collective choice arrangements and sanctioning activities for the use of common resources. Ostrom design principles were based on extensive studies of long-enduring governing institutions of common-pool resource management across different systems such as wildlife, fisheries, and forests (Ostrom 1990, 2009; Dell'Angelo et al., 2016). The eight design principles that were identified by Ostrom (1990) include opportunities for collective choice and local self-determination, approaches to monitoring, congruence with local conditions, sanctions, and conflict resolution. It included the incorporation of multiple, nested layers of organisation, shows the best practices, and describes the rules and structures of robust institutions associated with the sustainable governance of common pool resources. This study employed Ostrom's (1990) design principles for natural resource management as a diagnostic framework to analyse the CBNRM initiatives in the 21 case studies.

Table 1. Ostrom's 8 design principles for natural resource management of common-pool [Adapted from Ostrom (1990)]

\begin{tabular}{l|l}
\hline \multicolumn{1}{c|}{ Ostrom's design principles } & \multicolumn{1}{c}{ Operationalisation } \\
\hline 1. Clear boundaries & $\begin{array}{l}\text { Individuals or households who have the right } \\
\text { to use the common-pool resource are clearly } \\
\text { defined }\end{array}$ \\
2. Congruence with local conditions & $\begin{array}{l}\text { Rules restricting time, place, technology, and } \\
\text { quantity of resource use are well adapted to } \\
\text { local conditions }\end{array}$ \\
3. Collective-choice arrangements & $\begin{array}{l}\text { Most individuals affected by the rules can } \\
\text { participate in modifying them }\end{array}$ \\
4. Monitoring & $\begin{array}{l}\text { Common-pool resource conditions and use } \\
\text { are monitored by the users themselves or by } \\
\text { people accountable to the users }\end{array}$ \\
5. Graduated sanctions & $\begin{array}{l}\text { Users who violate resource-related rules are } \\
\text { likely to be assessed penalties that correspond } \\
\text { to the seriousness and context of the offense }\end{array}$ \\
\hline
\end{tabular}




\section{Conflict-resolution mechanisms}

7. Recognition of the right to organization
Users and officials have rapid access to lowcost local arenas for resolving conflicts among users and conflicts between users and officials

The rights of users to devise their own organisations are not challenged by external government authorities

Appropriation, provision, monitoring, enforcement, conflict resolution, and governance are organized in multiple, nested layers

CBNRM as a concept emerged and gained popularity in the early 1980s as an alternative to resource regimes that were perceived to be failing (Gibson and Mark, 1995; Matzke and Nabane, 1996). CBNRM has been extensively promoted in recent years as a method for investigating natural conservation and socio-economic goals. Examples such as forests, wetlands and grasslands are among several projects that involve local communities in managing natural resources in protected areas. Despite variation in forms of CBNRM such as the management by communities of wildlife, grassland, forests, water resources and many others, they share common features, including the involvement of local people in the management of their resources. This implies a willingness to devolve power and authority from central government to local institutions and people. This happens because of their belief and desire to integrate traditional ecological knowledge in balancing socio-economic and environmental goals in the conservation and protection of natural resources (Kellert et al., 2000).

CBNRM syntheses that has been conducted (Agrawal and Gibson, 1999; Allan and Curtis, 2005; Barkes, 2004; Campbell and Vainio-Mattila, 2003; Child, 2007; Deker et al., 2002; Gruber, 2010; Kellert et al., 2000; St. Jacques, 2009; Measham and Lumbasi, 2013) has been consistent with Ostrom's 1990 design principles for governing the common elements. Agrawal and Gibson (1999) proposed focusing on institutions rather than the community if CBNRM programmes are to be successful. Allan and Curtis (2005), in their study on adaptive management, found that using both passive and active adaptive management may be inhibited by deeply rooted social norms and institutional structures. Barkes (2004) proposes the need for greater consideration of the nature of people, communities and institutions, and how they interrelate at several levels in CBNRM programmes. In their synthesis of CBNRM, Kellert et al. (2000) note that the success of a CBNRM programme may depend on the structure of institutions, socioeconomic development and scientific considerations. They also observed that the main and consistent obstacle was a failure to control and monitor the behaviour of complex organisations, mostly bureaucratic and local institutions. Measham and Lumbasi (2013) further observed that communities with high level of ownership tend to have effective CBNRM programmes.

Assistance in the analysis of the current state of CBNRM initiatives was provided by Gruber (2010) who tried to develop wide organisational principles and main characteristics of effective and sustainable CBNRM. However, he could not recognise the key characteristics that were most critical in attaining long-term effective and 
sustainable CBNRM. Further, in his CBNRM synthesis, St. Jacques (2009) observes that participation needs to be flexible, not only to meet project phase objectives but also to allow for content-specific needs. He also observes that the most democratic form of participation is one that facilitates social learning and maximises the opportunity for information flows between stakeholders. Campbell and Vainio-Matilla (2003) also note in their study that lessons learned in participatory development have not been used in community-based conservation. This was partly because of the different emphasis on means versus ends in participatory development and community-based conservation. Furthermore, scholars such as Brooks et al. (2013) observed that Community-based conservation promoted the idea that long-term conservation success required engaging with and providing benefits for local communities. This was in line with Gurneya et al. (2016) who found that individuals' level of participation in marine protected areas (MPA) management was related to socioeconomic factors. In short, success in conservation is often predicated by local support for conservation which is influenced by perceptions of the impacts that are experienced by local communities and opinions of management and governance (Bannett and Dearden, 2014).

This review paper examined critically the success and failure of CBNRM that occurred in various case studies from 21 different countries based on the eight design principles developed by Ostrom (1990) that are displayed in Table 1 above.

\section{Methods}

To determine the relative success of CBNRM of the 21 case studies from the different countries, each variable was first given a score that was entered into a spread sheet. The scores were either 0 for no evidence or evidence not deemed useful or 1 for the existence of evidence provided in the case study. Second, the scores were then added to give a total value out of 8 . The higher the number, the greater was the relative success of the CBNRM initiative in each of the resources being managed in the 21 case studies. Third, the cross-tabulation analysis was performed using the variables scored in the spread sheet. Fisher's Exact Test in the cross-tabulation was used to analyse the relationship between each variable and the success of CBNRM. Fisher's Exact Test was appropriate for this study because of the small sample size used (21 cases). Data reduction techniques such as principal component analysis (PCA) could therefore not be used as it is recommended for a sample size of at least 50 and above (Hair et al., 2010).

\section{Results}

In Table 2, the countries where the case studies were done, as well as the name of the case study are shown. An indication is also given of the resource being managed and the source of data where the case study was reported. The resources managed in the case studies analysed included water, forest, wildlife, fish and wetlands. The case studies examined were drawn from different countries. Table 3 indicates the CBNRM performance criteria and the totals for the various case studies analysed. The CBNRM performance criteria analysed in the study include equity, empowerment, community participation, monitoring of biological diversity, conflict resolution, collective choice, and local condition rules. Table 3 indicates the total score for CBNRM performance criteria in each country, too. 
Spread sheet scores for cases studies examined are shown in Table 3. The table shows that for cases from Honduras up to Namibia, the total score for all the variables was 8, while Alaska, Washington, China and Papua New Guinea scored 7, but Botswana scored 2, with Nepal, Kenya, Zimbabwe and Tanzania scoring 0 for all the eight variables examined.

Table 2. Country of case study, type of case study type of resource managed and source of data

\begin{tabular}{|c|c|c|c|}
\hline Country & Name of case study & $\begin{array}{l}\text { Resource } \\
\text { managed }\end{array}$ & Data source \\
\hline Honduras & $\begin{array}{l}\text { Community-based water supply Pasos } \\
111\end{array}$ & Water & St Jacques 2009 \\
\hline India & $\begin{array}{c}\text { Holistic watershed management in } \\
\text { Sukhomojri }\end{array}$ & water & Islam and Jain 2011 \\
\hline Kenya & Mara river water association & Water & UNDP $2012 \mathrm{a}$ \\
\hline Nepal & Irrigation agriculture sector project & Water & Islam and Jain 2011 \\
\hline St Lucia & Water catchment project & Water & St Jacques 2009 \\
\hline Fiji & $\begin{array}{c}\text { Fiji Locally managed marine area } \\
\text { network }\end{array}$ & Water & UNDP 2012d \\
\hline India & Joint forest management & Forest & D'silva and Nagnath 2002 \\
\hline Mexico & Conservation forest management & & Brey et al., 2003 \\
\hline Malaysia & Regional awareness of Cameroon Island & Water & St Jacques 2009 \\
\hline Cambodia & Monk community forest & Forest & UNDP 2012 b \\
\hline Namibia & Conservancy and wildlife management & Wildlife & Jones 1999 \\
\hline Alaska & $\begin{array}{l}\text { Cooperative management of North } \\
\text { American Pacific salmon }\end{array}$ & Fish & Kellert et al., 2000 \\
\hline $\begin{array}{l}\text { Washington, } \\
\text { DC. }\end{array}$ & $\begin{array}{l}\text { Cooperative management of North } \\
\text { American Pacific salmon }\end{array}$ & Fish & Kellert et al., 2000 \\
\hline China & $\begin{array}{c}\text { Kanghua community development } \\
\text { centre }\end{array}$ & Forest & UNDP 2013 \\
\hline $\begin{array}{l}\text { Papua New } \\
\text { Guinea }\end{array}$ & Sepik wetlands management initiative & Wetlands & UNDP $2012 \mathrm{e}$ \\
\hline
\end{tabular}




\begin{tabular}{|c|c|c|c|}
\hline Botswana & CBNRM in Okavango Delta & Wildlife & Mbaiwa 2012 \\
\hline Nepal & $\begin{array}{c}\text { CBNRM in Annapuma and Makalu - } \\
\text { Barun }\end{array}$ & Wildlife & Kellert et al., 2000 \\
\hline Kenya & Kimana community wildlife sanctuary & Forest & Kellert et al., 2000 \\
\hline Zimbabwe & $\begin{array}{l}\text { Impact of CAMPFIRE on local } \\
\text { community }\end{array}$ & Wildlife & $\begin{array}{l}\text { Mutandwa and Gadzirayi } \\
2007\end{array}$ \\
\hline Uganda & $\begin{array}{l}\text { Wildlife conservation around Mburo } \\
\text { national park }\end{array}$ & Wildlife & Emerton 1999 \\
\hline Tanzania & Wildlife management in Serengeti & Wildlife & Emerton and Mfunda 1999 \\
\hline
\end{tabular}

Source: Compiled from literature, 2014

Table 3. Performance of CBNRM criteria and totals for the various case studies

\begin{tabular}{|c|c|c|c|c|c|c|c|c|c|}
\hline \multirow[t]{2}{*}{ Case study } & \multicolumn{8}{|c|}{ CBNRM performance criterion } & \multirow{2}{*}{ 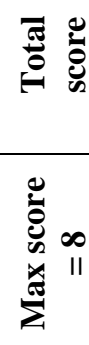 } \\
\hline & $\stackrel{\vec{E}}{:}$ & 崀离 & 㺼 & 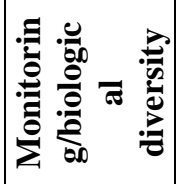 & 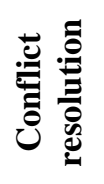 & 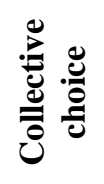 & 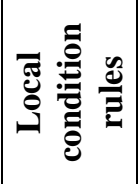 & 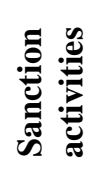 & \\
\hline Honduras & 1 & 1 & 1 & 1 & 1 & 1 & 1 & 1 & 8 \\
\hline $\begin{array}{l}\text { India water } \\
\text { case }\end{array}$ & 1 & 1 & 1 & 1 & 1 & 1 & 1 & 1 & 8 \\
\hline $\begin{array}{l}\text { Kenya water } \\
\text { case }\end{array}$ & 1 & 1 & 1 & 1 & 1 & 1 & 1 & 1 & 8 \\
\hline $\begin{array}{l}\text { Nepal water } \\
\text { case }\end{array}$ & 1 & 1 & 1 & 1 & 1 & 1 & 1 & 1 & 8 \\
\hline St Lucia & 1 & 1 & 1 & 1 & 1 & 1 & 1 & 1 & 8 \\
\hline Fiji & 1 & 1 & 1 & 1 & 1 & 1 & 1 & 1 & 8 \\
\hline $\begin{array}{l}\text { India joint } \\
\text { forest case }\end{array}$ & 1 & 1 & 1 & 1 & 1 & 1 & 1 & 1 & 8 \\
\hline $\begin{array}{l}\text { Mexico forest } \\
\text { case }\end{array}$ & 1 & 1 & 1 & 1 & 1 & 1 & 1 & 1 & 8 \\
\hline $\begin{array}{l}\text { Malaysia } \\
\text { water case }\end{array}$ & 1 & 1 & 1 & 1 & 1 & 1 & 1 & 1 & 8 \\
\hline
\end{tabular}




\begin{tabular}{c|c|c|c|c|c|c|c|c|c}
\hline Cambodia & 1 & 1 & 1 & 1 & 1 & 1 & 1 & 1 & 8 \\
$\begin{array}{c}\text { Namibia } \\
\text { wildlife }\end{array}$ & 1 & 1 & 1 & 1 & 1 & 1 & 1 & 1 & 8 \\
$\begin{array}{c}\text { Alaska goose } \\
\begin{array}{c}\text { Washington } \\
\text { fisheries }\end{array}\end{array}$ & 1 & 0 & 1 & 1 & 1 & 1 & 1 & 1 & 7 \\
$\begin{array}{c}\text { China } \\
\text { wildlife }\end{array}$ & 1 & 0 & 1 & 1 & 1 & 1 & 1 & 1 & 7 \\
$\begin{array}{c}\text { Papua New } \\
\text { Guinea }\end{array}$ & 1 & 0 & 1 & 1 & 1 & 1 & 1 & 1 & 7 \\
$\begin{array}{c}\text { Botswana } \\
\text { wildlife }\end{array}$ & 1 & 0 & 1 & 0 & 0 & 0 & 0 & 0 & 2 \\
$\begin{array}{c}\text { Nepal } \\
\text { wildlife }\end{array}$ & 0 & 0 & 0 & 0 & 0 & 0 & 0 & 0 & 0 \\
$\begin{array}{c}\text { Kenya } \\
\text { wildlife }\end{array}$ & 0 & 0 & 0 & 0 & 0 & 0 & 0 & 0 & 0 \\
$\begin{array}{c}\text { Zimbabwe } \\
\text { wildlife }\end{array}$ & 0 & 0 & 0 & 0 & 0 & 0 & 0 & 0 & 0 \\
$\begin{array}{c}\text { Nepal } \\
\text { wildlife }\end{array}$ & 0 & 0 & 0 & 0 & 0 & 0 & 0 & 0 & 0 \\
$\begin{array}{c}\text { Tanzania } \\
\text { wildlife }\end{array}$ & 0 & 0 & 0 & 0 & 0 & 0 & 0 & 0 & 0 \\
\hline
\end{tabular}

Cross-tabulation of the variables and CBNRM are shown in Appendix 1. The crosstabulation analysis was performed using scores from the spread sheet. The Fisher's Exact Test in the cross-tabulation reviews the relationship between each variable and the success of CBNRM. The Fisher exact test value $=17.008$ is significant at $5 \%$ level $(\mathrm{p}<0.05)$. We therefore reject the null hypothesis that there is no association between CBNRM and equity. This shows that for CBNRM initiative programme was successful, and equity needs met. From the cross tabulation Table 3 of CBNRM versus equity, it can be seen that if equity is absent, then CBNRM is not achieved. However, the table further shows that CBNRM can only be successful if equity is partially or fully achieved. The Fisher exact test is significant for the subsequent test of association between CBNRM and other variables examined. All the variables are important if CBNRM initiate is to be achieved (Table 3). For the entire cross tabulations for the variables assessed, Fisher exact test value is 0.00 indicating that all the variables need to be achieved to have a successful CBNRM initiative.

\section{Discussion}

We analysed CBNRM initiatives in 21 case studies from different countries using Ostrom's (1990) eight design principles of natural-resource management and eight 
objective measures. We found that some CBNRM initiatives show that their institutional structures reflect the eight design principles while others are not as discussed below. Those that were aligned with the design principles were successful while those that were not were unsuccessful. This is discussed more as follows.

\section{Gender and equity}

CBNRM advocates equal opportunities for men and women in natural resource management. Involving women in natural resource management programmes leads to positive outcomes, as women have a key influence on the environment (Songorwa, 1999). Gender balance has resulted in the success of most CBNRM initiatives where this was maintained. For example, the involvement of women in the management of forests in India led to success in that the first president of Vana Samarakshana Samith (VSS) is a woman and half of the members of the managing committee of VSS are women, too. The high involvement of women in India's forest management is attributed to the local demography of the area, which favours women (D'silva and Nagnath, 2002; Pathak and Gour-Broome, 1999). In Cambodia, a case study in the Monk Community Forest shows that women are actively encouraged to participate in CBNRM programmes; they are encouraged to take part in increasing awareness about activities in villages and to participate in the seven village sub-committees (UNDP, 2012a). In Mexico, there is strong participation of women in the management of activities in forests, such as bottling of water and tapping of resin (Bray, 2003). Gender balance is also a priority in the Fiji case study about a locally managed marine area network. There is a gender programme in which meetings are held with local women's groups that are encouraged to discuss the progress of the CBNRM initiative. This empowers women to make decisions on the management of their natural resources.

In the Honduras case study, dealing with the community-based supply of water and sanitation, sustainability is demonstrated through capacity building of the local community in water management, as water committees are established in the area. It is important to note that representation by women involved in decision-making did increase to $30 \%$ of the total number of individuals participating in the process of management (St. Jaques, 2009). This has led to an improvement in access to potable water and sanitation services in the area.

Some CBNRM initiatives, however, pays less attention to gender balance in their management of natural resources. This is the case in Zimbabwe's CAMPFIRE programme, where the participation of females is low (Mutandwa and Gadzirayi, 2007). Furthermore, in Nepal and Kenya women are marginalised (Kellert et al., 2000). In Botswana, Uganda and Tanzania the case studies did not provide information on how gender was addressed in their CBNRM initiatives.

Equal distribution of natural resource benefits to resource users motivates them to manage their resources sustainably. In Cambodia motivation to protect the forest emanates from the material benefits the forest offered to the local people, which are distributed equally to all the resource users (UNDP, 2012b). In Washington, the CBNRM initiative is a success because of the benefits from the natural resources that are distributed equally, which is evident from the lower number of conflicts that are registered in the case study (Kellert et al., 2000). When natural resource benefits are not distributed equally to all resource users, it tends to lead to conflicts. In Papua New Guinea, the CBNRM initiative provides benefits to the community in the form of economic benefits from the wetland resources hence it is a success (UNDP, 2012d). In 
India, local communities have equal access to forests and have employment opportunities in the forest work, therefore, they are motivated to protect the forest (Pathak and Gour-Broome, 1999). In their study on the effect of equity in benefit sharing in Nepal community forest programme, Luintel et al. (2017) noted that equity has been crucial in motivating forest managing communities.

In some case studies, however, equal distribution of natural resource benefits to all beneficiaries is a failure, and this leads to deficiencies in managing the natural resources effectively and in a sustainable manner. For example, case studies from Kenya, Nepal, Tanzania, Uganda and Zimbabwe reflect the unequal distribution of natural resource benefits. In Kenya, only a small minority received monetary benefits, while in Nepal there is uneven allocation of natural resources. This is because local people living closer to CBNRM headquarters receive more development benefits than those who live further from the headquarters in both Annapurna conservation areas (ACA) and Makulu barun conservation area (MBCA) (Kellert et al., 2000). In Zimbabwe's CAMPFIRE programme, the local community receives no economic benefits from their natural resources (Mutandwa and Gadzirayi, 2007). In Botswana unequal distribution of benefits occurs, as only $40 \%$ of the locals benefit from the wildlife resources (Boggs, 2000). Failure to distribute resource benefits equally to all beneficiaries leads to conflicts in the community and also reduces interest in managing natural resources effectively.

\section{Monitoring}

Ostrom's 1990 design principles advocate effective monitoring procedures in the management of common pool regimes. In the Mexico case study, effective monitoring is demonstrated by the expansion of canopy from 1982 to 1993, where the communities place four hectares under strict protection for the conservation of the endangered species Hickel's fir (Adies hickelii). The certification of 502,656 ha of forest in 2002 in 25 communities under the criteria of the forest stewardship council and the declaration of 500,000 ha in 1980 by the state of Quintana Roo as permanent forest areas demonstrates an increase in re-afforestation by the community, with limits being placed on agricultural activities in the forest area. Other monitoring indicators in Mexico include prohibiting all hunting activities in forest areas and willingness to reduce the logging volume in the Quintana Roo community and Laguna Kana' from 29\% and 37\% respectively (Bray, 2003). Effective monitoring procedures are also observed in Puget Sound in the State of Washington where ecological information on various salmon stocks has improved, and coordination of conservation efforts is enhanced among stakeholders (Kellert et al., 2000). The same happened in India, where a reduction in the demand for firewood is noted (D'silva and Nagnath, 2002). In the case of community water resources management in India, the programme has an ecological impact, namely an increase in the availability of water, as several rivers became perennial. There is also an increase in agricultural productivity where wheat yields are doubling (Islam and Jain, 2011).

However, in some case studies, there are no effective procedures to monitor natural resources. In Kenya for example, there is insufficient monitoring of observations of the wildlife resource because patrols by game scouts are highly sporadic. Data collected on the wildlife population and their habitats and on ecologically threatened and endangered species are insufficient. Moreover, little data collection on the dynamics of wildlife populations in the area and encroachment on the habitats of wildlife resources in parts 
of the Kimani community wildlife sanctuary (KCWS), take place (Kellert et al., 2000). In Nepal, a case study in the Annapuna and Makalu-Barun areas reveals that little time is being devoted to monitoring and protecting biological diversity, as most of the work is focused on building and local communities (Kellert et al., 2000). There is also insufficient monitoring of wildlife resources in Botswana and Zimbabwe, as no information is available to indicate the dynamics of resources in the study areas (Mbaiwa, 2012). The picture is similar in Tanzania and Uganda for their wildlife management case studies.

In summary, gender balance, equity and effective monitoring of natural resources are important for the success of a CBNRM initiative. This is because they all lead to the sustainability of natural resources.

\section{Devolution and empowerment}

Design principles developed by Ostrom in 1990 also advocate defined membership and rights in the management of common pool regimes. This is because devolution empowers resources (Armitage, 2005; Child, 2007; Grumbine, 1994). Measham and Lumbasi (2013) observe that communities with high level of ownership tend to have effective CBNRM programmes. Therefore, local communities will only be empowered if devolution is fully achieved. Empowering local communities builds commitment in the users of natural resources to manage such resources effectively (Bannett and Dearden (2014). Unfortunately, where local communities are not empowered to manage their natural resources, they usually remain unmotivated, and this has a negative effect on the well-being of the natural resources that are available. In all the case studies that are examined, attempts are made to devolve authority from the state to the local power, but the effectiveness of that devolution is variable. For example, in Kenya devolution of authority usually results in power being concentrated in certain groups or members, with others being excluded, and in Nepal people of a low caste and women are underrepresented in conducting the management of natural resources (Kellert et al., 2000). Empowerment is also lacking in Zimbabwe's CAMPFIRE programme, where Mutandwa and Gadzirayi, 2007) observes partial devolution of natural resources and the exclusion of the local people in decision-making and management. In Botswana, too, despite job creation related to wildlife activities, no empowerment is seen among the local people (Mbaiwa, 2012), as the management of the resources is entirely in the hands of the government (Boggs, 2000).

In Fiji, the locally managed marine area within the network was established in 1997 in the Ucinivanua community, where the local community are empowered through the building of on-going capacity with the necessary knowledge to reverse the decline in their natural resources. Also, the emphasis is placed on the importance of collecting data as a tool for learning, alongside on-site training workshops and encouragement in the use of adaptive management as a key to achieving best practices. Moreover, a network has been developed that recognises the autonomy of the local communities' management of their marine resources, while providing support and guidance to help them achieve the best results and take responsibility for planning and facilitating the programme, while decision-making, implementation and evaluation are undertaken on ground level by the individual groups (Gruber, 2010).

The situation concerning empowerment is different in Alaska, Cambodia, China, Fiji, India, Japan, Malaysia, Mexico, Namibia, Papua New Guinea, St Lucia and Washington. In Alaska's Kuskokwim River watershed the local community is 
empowered to manage their salmon resource. In Cambodia, the programme for the management of natural resources has empowered the participants to have a voice in the management of the community forest through their representatives on the central management committee and the sub-committees (UNDP, 2012b). In China, the Kanghua community placed a strong emphasis on ownership of the natural resource by the local people, giving the community a strong sense of engagement and commitment that leads to the success of the initiative. The management programme for sika deer in Japan also empowers the local community, as they are involved in the decision-making process through the Nishiokoppe Wildlife Steering Committee (Decker et al., 2002). The same happens in Cambodia, where the participants have a voice in the management of the community forest through their representatives on the central management committee and the sub-committees. The importance of empowerment is further demonstrated by the Malaysian case where the World Wide Fund for Nature (WWF) withdrew its support in 2004. They also withdrew funding for the initiative of the Regional Environmental Awareness of Cameroon Highlands (REACH). Thereafter, funding was entirely depended on membership fees, donations and fundraising ventures (St Jacques, 2009). This confirms the empowerment of the local community to manage their resources by a non-governmental organisation because the initiative continues even after support is withdrawn.

In Mexico, devolution of responsibility for forest resources to the local communities is about $80 \%$ (Bray, 2003). The Mexican case also clearly shows that large numbers of communities are managing common property forests for commercial production of timber and finished timber products in some areas in Mexico, unlike in less developed countries where community forest management usually entails the management of nontimber forest products or wood for domestic use on government land (Bray, 2003). In St Lucia's water catchment project, community empowerment is demonstrated by the full participation of the local community and through capacity building in the various awareness programmes that are offered. Examples of this are technical training sessions and exchange programmes with similar community-based organisations, both in St Lucia and elsewhere (St Jacques, 2009). In Washington, the indigenous people are empowered through a partnership with the fisheries department, which gives them sufficient legal rights and authority to manage their local fisheries (Kellert et al., 2000).

\section{Conflict resolution}

Cheap or accessible conflict resolution mechanisms are one of the key principles designed by Ostrom (1990) in the management of common pool regimes. Conflicts in CBNRM programmes cannot be avoided, as management involves many stakeholders who have an interest in the natural resources. It is therefore important for CBNRM to factor in conflict resolution strategies at the start of the programmes (Ostrom, 1990). In the cases analysed, conflict resolution is addressed well in all of the water cases mentioned. In case studies of wildlife management in Kenya, Tanzania, Botswana, Zimbabwe China, and Nepal, however, conflicts are rarely resolved. For example, in all of these case studies, natural resource conflicts frequently occur, although the sources of conflict vary from place to place. In Kenya conflicts arise from wildlife depredation and disputes with neighbouring group ranches over boundary delineations and those related to institutional posts (Kellert et al., 2000. These cases are rarely resolved by management in the area, and little or no compensation is provided for damage caused by wildlife. In Nepal, the causes of conflicts are mostly related to power struggles among 
members and members of the institutions, especially the elite. Local conflicts in institutions also occur in the area as a result of overlapping jurisdictions and mandates (Heines and Mehta, 1999). In Tanzania, conflicts did arise from serious crop damage, usually caused by wildlife in the study area, but no compensation is paid for the damage that occurs (Emerton, 1999). The case is the same in Botswana and Zimbabwe, where community conflicts are on the increase but rarely resolved and no compensation for wildlife damage is paid (Mutandwa and Gadzirayi, 2007; Mbaiwa, 2012). Empowerment and conflict resolution lead to the sustainability of natural resources, and therefore CBNRM programmes could be successful.

\section{Participation}

Another of Ostrom (1990)'s key principles for enduring common pool institutions is collective choice arrangements. This allows the local community to participate in the decision-making process through village institutions and several committees. Community participation in natural resource management is one of the pillars of CBNRM (Mbaiwa, 2012) and is usually the outcome of sustainable CBNRM. When resource users can derive economic benefits from their resources, they tend to develop positive attitudes to natural resources and therefore use them sustainably, and this promotes participation among them (Gurneya et al., 2016). However, if the benefits are not realised by the local community, they usually become demotivated, and this frequently destroys participation, since the unsustainable use of resources is the outcome. The holistic watershed management in Sukhomojri, India shows that active participation of the local community is needed for the conservation and management of extraction of timber for firewood, brought about by its increased scarcity. It demonstrates that the local community should take an active part in the management of their natural resources (Pathek and Gour-Broone, 1999). The motivation to participate in natural resource management derives from benefits that the resource users receive from the natural resource (UNDP, 2012e). In water resources management in India, the local community in village assemblies is fully involved in determining the management of the watershed, distribution of water, rules about annual repairs as well as penalties for users of unsustainable natural resources Islam and Jain, 2011). Effective participation is also shown in a water case in India where villagers are allowed to make decisions on the management of their water resource through village institutions; several committees are democratically formed in the area. Participation of the local community in the St Lucia water case is sustained by encouragement from the management of the responsible use of natural resources, as well as direct and indirect monetary incentives. Awareness and demonstrations offered to the local community in the study area are important, too (St Jacques, 2009). Often, local community participation in the case studies is low. In Tanzania, Uganda, Nepal and Kenya local participation is also low in the cases examined (Emerton and Mfunda, 1999; Kellert et al., 2000). However, in Botswana, the situation is different, as local community participation is observed (Mbaiwa, 2012). Active participation of the local community in natural resource management is an important element of a successful CBNRM initiative. The sustainability of natural resources is therefore guaranteed if the local community is actively involved in the management of the resources through various committees and village institutions where they are free to make decisions on matters related to their natural resources.

Fisher's Exact Test analysis of the cross-tabulation of the variables further indicates that for a CBNRM initiative to be successful, all eight variables are important. Of the 21 
cases analysed, 11 are successful in their CBNRM programmes, five are partially successful while the last five are not successful (Table 2). This is because the Fisher's Exact Test P-value in all the variables analysed was .00, which was less than .5, indicating a significant relationship between each variable and the success of the CBNRM initiative (Appendix 1). This shows that all the variables assessed in the review, are all important for CBNRM initiative to be successful.

\section{Conclusion}

This study analysed CBNRM initiatives in 21 case studies from different countries based on the application of Ostrom (1990)'s eight design principles of common pool regimes to the management of natural resources. The various aspects of the 21 case studies were examined and grouped into the sustainability of natural resources, social institutions sustainability and livelihood sustainability. To ascertain the sustainability of the CBNRM programme in each of the case studies mentioned above, all three areas were examined. All three aspects of sustainability are evident in the successful cases. Most of the dimensions of social institutions' sustainability are achieved by the case studies, such as equity, participation, sense of community ownership, social coherence and encouraging diversity in the community. Livelihood sustainability is also achieved by the cases that achieved a high scoring. Dimensions of livelihood sustainability that were examined include economic and indirect benefits, for example in the areas of education and health, where infrastructure was built to ensure that the community would satisfy its basic needs so as to foster good quality of life in the communities. Natural resource sustainability was achieved in a few cases, as there seemed to be a challenge in balancing the social and natural aspects of sustainability. However, cases from North America seem to have no problem with that, as evidenced by the study. Natural resource sustainability is a major problem in cases from Africa and Asia. Dimensions examined include monitoring and proof of biodiversity protection. Cases that did not score high in the social sustainability and livelihood sustainability dimensions seem to have problems in protecting their natural resources. A successful CBNRM programme is possible when the resource users are motivated to take care of their resources. When the resource users are not motivated, the result is the unsustainable use of resources, which leads to failure in the CBNRM initiative. It is therefore important to promote the social and livelihood aspects of sustainability, such as equity, participation, rights and empowerment, collective choice and conflict mechanisms, to have a successful CBNRM programme. It is recommended that further studies be conducted with larger sample sizes utilising different techniques for increasing the understanding of multiple factors that are essential for achieving effective and sustainable CBNRM initiatives.

\section{REFERENCES}

[1] Allan, C., Curtis, A. (2005): Nipped in the bud: Why regional scale adaptive management is not blooming. - Environmental Management 36: 414-425

[2] Agrawal, A., Gibson, C. C. (1999): Enchantment and disenchantment: the role of the community in natural resource conservation. - World Development 27: 629-649

[3] Armitage, D. (2005): Adaptive capacity and Community-Based Natural Resource Management. - Environmental Management 35: 703-715

[4] Bennett, N. J., Dearden, P. (2014): Why local people do not support conservation: Community perceptions of marine protected area livelihood impacts, governance and management in Thailand. - Marine Policy 44: 107-116 
[5] Berkes, F. (2004): Rethinking community-based conservation. - Conservation Biology 18 (3): 621-630

[6] Boggs, L. P. (2000): Community Power, Participation, Conflict and Development Choice: Community Wildlife Conservation in the Okavango Region of Northern Botswana. - Evaluating Eden Discussion Paper No. 17., IIED, London

[7] Bray, D. B. (2003): Mexico's community managed forests as a model for sustainable landscapes. - Conservation Biology 17 (3): 672-677

[8] Brooks, J., Waylen K. A., Mulder, M. B. (2013): Assessing community-based conservation projects: A systematic review and multilevel analysis of attitudinal, behavioural, ecological, and economic outcomes. - Environmental Evidence 2:2

[9] Campbell, L. M., Vainio-Mattila, A. (2003): Participatory development and community based conservation: Opportunities missed and lessons learned? - Human Ecology 31: 417-437

[10] Child, B. (2007): Lessons, experiences, and critical conditions for CBNRM. Can communities' conservation bring international goals down to earth? Chairman's report from a workshop on the Millennium Ecosystem Assessment. - Nordic Council of Ministers, Copenhagen, Denmark.

[11] Decker D. J., Lauber, B. L., Siemer, W. F (2002): Human conflict management . A practitioner guide. - Human research unit Cornell University, Ithaca, New York.

[12] Dell'Angelo, J., McCord, P. F., Gower, D., Carpenter, S., Caylor, K. K., Evans, T. P. (2016): Community Water Governance on Mount Kenya: An Assessment Based on Ostrom's Design Principles of Natural Resource Management. - Mountain Research and Development, 36 (1): 102-115.

[13] D'silva, E., Nagnath, B. (2002): Behroonguda: A rare success story in Joint forestry management. - Economic and political weekly 37 (6): 551-557

[14] Emerton, L., Mfunda, I. (1999): Making Wildlife Economically Viable for Communities Living Around the Western Serengeti, Tanzania. - Evaluating Eden Discussion Paper No. 1. IIED, London.

[15] Emerton, L. (1999): Balancing the Opportunity Costs of Wildlife Conservation for Communities around Lake Mburo National Park, Uganda. - Evaluating Eden Discussion Paper No. 5. IIED, London.

[16] Gibson, C., Marks, S. (1995): Transforming rural hunters into conservationists. "An assessment of community-based wildlife management Programmes in Africa". - World Development 23 (6) 941-957

[17] Gruber, S. J. (2010): Key principles of CBNRM: A synthesis and interpretation of identified effective approaches for managing the commons. - Environment and Management 45: 52-66

[18] Grumbine, R. E. (1994): What is ecosystem management? - Conservation Biology 8:2738

[19] Gurneya, G. G., Cinnera, J. E., Sartinb, J., Presseya, R. L., Banc, N. C., Marshalld, N. A., Prabuning, D. (2016): Participation in devolved commons management: Multistage socioeconomic factors related to individuals' participation in community-based management of marine protected areas in Indonesia. - Environmental Science and Policy 61: 212-220

[20] Hair, J. F. Jr, Black, W. C., Babin, J. B., Anderson, R. (2010): Multivariate data analysis. - Pearson New International Edition, $7^{\text {th }}$ edition, Pearson, UK.

[21] Heinen, J. T., Mehta, J. N. (1999): Conceptual and legal issues in the designation and management of conservation areas in Nepal. - Environmental Conservation 26 (1): 21-29.

[22] Islam, K. M. B., Jain, C. K. (2011): Community based water resources in North East India: Lessons from a Global context. - Allied New Delhi, 3-12

[23] Jones, B. (1999): Rights, Revenues and Resources: The problems and potential of Conservancies as community wildlife management institutions in Namibia. Evaluating Eden, Discussion Paper No. 2. IIED, London. 
[24] Kellert, S. R., Mehta, J. N., Ebbin, S. A., Lichtenfeld, L. L. (2000): Community natural resource management: Promise, Rhetoric and Reality. - Society and natural resources 13: 705-713

[25] Luintel, H., Randall A. Bluffstone, R. A., Scheller, R. M, and Adhikari, B. (2017): The Effect of the Nepal Community Forestry Program on Equity in Benefit Sharing. - Journal of Environment and Development 0(0): 1-25

[26] Matzke, G. E., Nabane, N. (1996): Outcomes of a community controlled wildlife utilization program in a Zambezi Valley Community. - Human Ecology 24 (1): 65-85.

[27] Mbaiwa, J. E. (2012): Botswana's community based natural resource management status report for 2011/2012. - Gaborone: Kalahari conservation society.

[28] Meashan, T.G., Lumbasi, J. A (2013): Success Factors for Community-Based Natural Resource Management (CBNRM): Lessons from Kenya and Australia.- Environmental Management 52: 649-659.

[29] Mutandwa, E., Gadzirayi, C. T. (2007): Impact of community based approaches to wildlife management: Case study of the CAMPFIRE programme in Zimbabwe. International Journal of Sustainable Development and World Ecology 14: 336-344

[30] Nabane, N., Matzke, G. (1997): A gender-sensitive analysis of a community-based wildlife utilization initiative in Zimbabwe's Zambezi Valley. - Society and Natural Resources 10 (6): 519- 535

[31] Ostrom, E. (2009): A general framework for analysing sustainability of social ecological systems. - Science 325(5939):419-422.

[32] Ostrom, E. (1990): Governing the commons. - Cambridge University Press, New York, NY.

[33] Pathak, N., Gour-Broome, V. (1999): Tribal Self-Rule and Natural Resource Management: Community Based Conservation in Mendha (Lekha), Maharashtra, India. Kalpavriksh, New Delhi/Pune and International Institute of Environment and Development, London.

[34] Songorwa, A. N. (1999): Community based wildlife management (CWM) in Tanzania: Are the communities interested? - World Development 27 (12): 2061-2079

[35] St Jacques, M. C. (2009): Community water strategies: A framework for implementation. Working document. - Brace Centre for Water Resources Management McGill University, Montreal, Canada

[36] United Nations Development Programme. (2012a): Mara River Water Users Association, Kenya. - Equator Initiative case study series, New York, NY.

[37] United Nations Development Programme. (2012b): Monks Community Forest, Cambodia. - Equator Initiative Case Study Series, New York, NY.

[38] United Nations Development Programme. (2013): Kanghua Community Development Centre, China. - Equator Initiative Case Study Series, New York, NY.

[39] United Nations Development Programme. (2012c): Makuleke Ecotourism Project - Pafuri Camp, South Africa. - Equator Initiative Case Study Series, New York, NY.

[40] United Nations Development Programme. (2012d): Fiji Locally-Managed Marine Area Network, Fiji. - Equator Initiative Case Study Series, New York, NY.

[41] United Nations Development Programme. (2012e): Sepik Wetlands Management Initiative, Papua New Guinea. - Equator Initiative Case Study Series, New York, NY. 


\section{APPENDIX}

Appendix 1. Cross-tabulation analysis of variables

\section{$C B N R M * E q u i t y$}

Cross-tabulation

\begin{tabular}{|c|c|c|c|c|c|}
\hline & & & & & \\
\hline & & & Absent & Present & \\
\hline & & Count & 5 & $0_{\mathrm{b}}$ & 5 \\
\hline & Not Achieved & $\%$ within CBNRM & $100.0 \%$ & $0.0 \%$ & $100.0 \%$ \\
\hline & & $\%$ within equity & $100.0 \%$ & $0.0 \%$ & $23.8 \%$ \\
\hline & & Count & $0_{\mathrm{a}}$ & $5 \mathrm{a}$ & 5 \\
\hline CBNRM & $\begin{array}{l}\text { Partially } \\
\text { Achieved }\end{array}$ & $\%$ within CBNRM & $0.0 \%$ & $100.0 \%$ & $100.0 \%$ \\
\hline & & $\%$ within equity & $0.0 \%$ & $31.3 \%$ & $23.8 \%$ \\
\hline & & Count & $0_{\mathrm{a}}$ & $11_{\mathrm{b}}$ & 11 \\
\hline & Achieved & $\%$ within CBNRM & $0.0 \%$ & $100.0 \%$ & $100.0 \%$ \\
\hline & & $\%$ within equity & $0.0 \%$ & $68.8 \%$ & $52.4 \%$ \\
\hline & & Count & 5 & 16 & 21 \\
\hline & tal & $\%$ within CBNRM & $23.8 \%$ & $76.2 \%$ & $100.0 \%$ \\
\hline & & $\%$ within equity & $100.0 \%$ & $100.0 \%$ & $100.0 \%$ \\
\hline
\end{tabular}

Each subscript letter denotes a subset of equity categories whose column proportions do not differ significantly from each other at the .05 level.

\begin{tabular}{c|c|c|c|c|c|c}
\hline \multicolumn{7}{c}{ Chi-Square Tests } \\
\hline & Value & df & $\begin{array}{c}\text { Asymptotic } \\
\text { Significance } \\
\text { (2-sided) }\end{array}$ & $\begin{array}{c}\text { Exact } \\
\text { Sig. (2- } \\
\text { sided) }\end{array}$ & $\begin{array}{c}\text { Exact Sig. } \\
\text { (1-sided) }\end{array}$ & $\begin{array}{c}\text { Point } \\
\text { Probability }\end{array}$ \\
\hline Pearson Chi-Square & $21.000^{\mathrm{a}}$ & 2 & .000 & .000 & & \\
Likelihood Ratio & 23.053 & 2 & .000 & .000 & & \\
Fisher's Exact Test & 17.008 & & & .000 & & \\
Linear-by-Linear \\
$\begin{array}{c}\text { Association } \\
\text { N of Valid Cases }\end{array}$ & $15.188^{\mathrm{b}}$ & 1 & .000 & .000 & .000 & .000 \\
\hline
\end{tabular}

a. 5 cells $(83.3 \%)$ have expected count less than 5 . The minimum expected count is 1.19 .

b. The standardised statistic is 3.897 . 


\begin{tabular}{|c|c|c|c|c|c|}
\hline \multicolumn{6}{|c|}{ Cross-tabulation } \\
\hline & & & \multicolumn{2}{|c|}{ Empowerment } & \multirow{2}{*}{ Total } \\
\hline & & & Absent & Present & \\
\hline \multirow{9}{*}{ CBNRM } & \multirow{3}{*}{ Not Achieved } & Count & $5 \mathrm{a}$ & $0_{\mathrm{b}}$ & 5 \\
\hline & & $\%$ within CBNRM & $100.0 \%$ & $0.0 \%$ & $100.0 \%$ \\
\hline & & $\%$ within empowerment & $50.0 \%$ & $0.0 \%$ & $23.8 \%$ \\
\hline & \multirow{3}{*}{$\begin{array}{l}\text { Partially } \\
\text { Achieved }\end{array}$} & Count & $5 \mathrm{a}$ & $0_{\mathrm{b}}$ & 5 \\
\hline & & $\%$ within CBNRM & $100.0 \%$ & $0.0 \%$ & $100.0 \%$ \\
\hline & & $\%$ within empowerment & $50.0 \%$ & $0.0 \%$ & $23.8 \%$ \\
\hline & \multirow{3}{*}{ Achieved } & Count & $0_{\mathrm{a}}$ & $11_{\mathrm{b}}$ & 11 \\
\hline & & $\%$ within CBNRM & $0.0 \%$ & $100.0 \%$ & $100.0 \%$ \\
\hline & & $\%$ within empowerment & $0.0 \%$ & $100.0 \%$ & $52.4 \%$ \\
\hline \multirow{3}{*}{\multicolumn{2}{|c|}{ Total }} & Count & 10 & 11 & 21 \\
\hline & & $\%$ within CBNRM & $47.6 \%$ & $52.4 \%$ & $100.0 \%$ \\
\hline & & $\%$ within empowerment & $100.0 \%$ & $100.0 \%$ & $100.0 \%$ \\
\hline
\end{tabular}

Each subscript letter denotes a subset of empowerment categories whose column proportions do not differ significantly from each other at the .05 level.

\section{Chi-Square Tests}

\begin{tabular}{|c|c|c|c|c|c|c|}
\hline & Value & Df & $\begin{array}{l}\text { Asymptotic } \\
\text { Significance }\end{array}$ & $\begin{array}{c}\text { Exact Sig. } \\
\text { (2-sided) }\end{array}$ & $\begin{array}{c}\text { Exact Sig. } \\
\text { (1-sided) }\end{array}$ & $\begin{array}{c}\text { Point } \\
\text { Probability } \\
\end{array}$ \\
\hline Pearson Chi-Square & $21.000^{\mathrm{a}}$ & 2 & .000 & .000 & & \\
\hline Likelihood Ratio & 29.065 & 2 & .000 & .000 & & \\
\hline Fisher's Exact Test & 22.076 & & & .000 & & \\
\hline $\begin{array}{l}\text { Linear-by-Linear } \\
\text { Association }\end{array}$ & $16.500^{\mathrm{b}}$ & 1 & .000 & .000 & .000 & .000 \\
\hline $\mathbf{N}$ of Valid Cases & 21 & & & & & \\
\hline
\end{tabular}

a. 4 cells $(66.7 \%)$ have expected count less than 5 . The minimum expected count is 2.38 .

b. The standardised statistic is 4.062 . 


\begin{tabular}{|c|c|c|c|c|c|}
\hline \multicolumn{6}{|c|}{ Cross-tabulation } \\
\hline & & & \multicolumn{2}{|c|}{ Participation } & \multirow{2}{*}{ Total } \\
\hline & & & Absent & Present & \\
\hline \multirow{9}{*}{ CBNRM } & \multirow{3}{*}{ Not Achieved } & Count & $5_{\mathrm{a}}$ & $0_{\mathrm{b}}$ & 5 \\
\hline & & $\%$ within CBNRM & $100.0 \%$ & $0.0 \%$ & $100.0 \%$ \\
\hline & & $\%$ within participation & $100.0 \%$ & $0.0 \%$ & $23.8 \%$ \\
\hline & \multirow{3}{*}{$\begin{array}{l}\text { Partially } \\
\text { Achieved }\end{array}$} & Count & $0_{\mathrm{a}}$ & $5_{\mathrm{a}}$ & 5 \\
\hline & & $\%$ within CBNRM & $0.0 \%$ & $100.0 \%$ & $100.0 \%$ \\
\hline & & $\%$ within participation & $0.0 \%$ & $31.3 \%$ & $23.8 \%$ \\
\hline & \multirow{3}{*}{ Achieved } & Count & $0_{\mathrm{a}}$ & $11_{\mathrm{b}}$ & 11 \\
\hline & & $\%$ within CBNRM & $0.0 \%$ & $100.0 \%$ & $100.0 \%$ \\
\hline & & $\%$ within participation & $0.0 \%$ & $68.8 \%$ & $52.4 \%$ \\
\hline \multirow{3}{*}{\multicolumn{2}{|c|}{ Total }} & Count & 5 & 16 & 21 \\
\hline & & \% within CBNRM & $23.8 \%$ & $76.2 \%$ & $100.0 \%$ \\
\hline & & $\%$ within Participation & $100.0 \%$ & $100.0 \%$ & $100.0 \%$ \\
\hline
\end{tabular}

Each subscript letter denotes a subset of participation categories whose column proportions do not differ significantly from each other at the .05 level.

Chi-Square Tests

\begin{tabular}{|c|c|c|c|c|c|c|}
\hline & Value & Df & $\begin{array}{c}\text { Asymptotic } \\
\text { Significance } \\
\text { (2-sided) }\end{array}$ & $\begin{array}{l}\text { Exact Sig. } \\
\text { (2-sided) }\end{array}$ & $\begin{array}{l}\text { Exact Sig. } \\
\text { (1-sided) }\end{array}$ & $\begin{array}{c}\text { Point } \\
\text { Probability }\end{array}$ \\
\hline Pearson Chi-Square & $21.000^{\mathrm{a}}$ & 2 & .000 & .000 & & \\
\hline Likelihood Ratio & 23.053 & 2 & .000 & .000 & & \\
\hline Fisher's Exact Test & 17.008 & & & .000 & & \\
\hline $\begin{array}{c}\text { Linear-by-Linear } \\
\text { Association }\end{array}$ & $15.188^{b}$ & 1 & .000 & .000 & .000 & .000 \\
\hline $\mathbf{N}$ of Valid Cases & 21 & & & & & \\
\hline
\end{tabular}

a. 5 cells $(83.3 \%)$ have expected count less than 5 . The minimum expected count is 1.19 .

b. The standardised statistic is 3.897 . 


\begin{tabular}{|c|c|c|c|c|c|}
\hline \multicolumn{6}{|c|}{ Cross-tabulation } \\
\hline & & & \multicolumn{2}{|c|}{$\begin{array}{c}\text { Monitoring / Biological } \\
\text { diversity }\end{array}$} & \multirow{2}{*}{ Total } \\
\hline & & & Absent & Present & \\
\hline \multirow{9}{*}{ CBNRM } & \multirow{4}{*}{$\begin{array}{l}\text { Not } \\
\text { Achieved }\end{array}$} & Count & $5 \mathrm{a}$ & $0_{\mathrm{b}}$ & 5 \\
\hline & & $\%$ within CBNRM & $100.0 \%$ & $0.0 \%$ & $\begin{array}{c}100.0 \\
\%\end{array}$ \\
\hline & & $\begin{array}{c}\% \text { within monitoring/ biological } \\
\text { diversity }\end{array}$ & $83.3 \%$ & $0.0 \%$ & $23.8 \%$ \\
\hline & & Count & $1_{\mathrm{a}}$ & $4 a$ & 5 \\
\hline & \multirow[t]{2}{*}{$\begin{array}{l}\text { Partially } \\
\text { Achieved }\end{array}$} & $\%$ within CBNRM & $20.0 \%$ & $80.0 \%$ & $\begin{array}{c}100.0 \\
\%\end{array}$ \\
\hline & & $\begin{array}{c}\% \text { within monitoring/ biological } \\
\text { diversity }\end{array}$ & $16.7 \%$ & $26.7 \%$ & $23.8 \%$ \\
\hline & \multirow{3}{*}{ Achieved } & Count & $0_{\mathrm{a}}$ & $11_{\mathrm{b}}$ & 11 \\
\hline & & $\%$ within CBNRM & $0.0 \%$ & $100.0 \%$ & $\begin{array}{c}100.0 \\
\%\end{array}$ \\
\hline & & $\begin{array}{c}\% \text { within monitoring/ biological } \\
\text { diversity }\end{array}$ & $0.0 \%$ & $73.3 \%$ & $52.4 \%$ \\
\hline \multirow{3}{*}{\multicolumn{2}{|c|}{ Total }} & Count & 6 & 15 & 21 \\
\hline & & $\%$ within CBNRM & $28.6 \%$ & $71.4 \%$ & $\begin{array}{c}100.0 \\
\%\end{array}$ \\
\hline & & $\begin{array}{c}\% \text { within monitoring/ biological } \\
\text { diversity }\end{array}$ & $100.0 \%$ & $100.0 \%$ & $\begin{array}{c}100.0 \\
\%\end{array}$ \\
\hline
\end{tabular}

Each subscript letter denotes a subset of monitoring/biological diversity categories whose column proportions do not differ significantly from each other at the .05 level.

\section{Chi-Square Tests}

\begin{tabular}{|c|c|c|c|c|c|c|}
\hline & Value & Df & $\begin{array}{c}\text { Asymptotic } \\
\text { Significance } \\
\text { (2-sided) }\end{array}$ & $\begin{array}{l}\text { Exact Sig. } \\
\text { (2-sided) }\end{array}$ & $\begin{array}{l}\text { Exact Sig. } \\
\text { (1-sided) }\end{array}$ & $\begin{array}{c}\text { Point } \\
\text { Probability }\end{array}$ \\
\hline Pearson Chi-Square & $17.080^{\mathrm{a}}$ & 2 & .000 & .000 & & \\
\hline Likelihood Ratio & 20.123 & 2 & .000 & .000 & & \\
\hline Fisher's Exact Test & 15.515 & & & .000 & & \\
\hline $\begin{array}{l}\text { Linear-by-Linear } \\
\text { Association }\end{array}$ & $14.727^{\mathrm{b}}$ & 1 & .000 & .000 & .000 & .000 \\
\hline$N$ of Valid Cases & 21 & & & & & \\
\hline
\end{tabular}

a. 5 cells $(83.3 \%)$ have expected count less than 5 . The minimum expected count is 1.43 .

b. The standardised statistic is 3.838 . 


\begin{tabular}{|c|c|c|c|c|c|}
\hline \multicolumn{6}{|c|}{ Cross-tabulation } \\
\hline & & & \multicolumn{2}{|c|}{ Conflict resolution } & \multirow{2}{*}{ Total } \\
\hline & & & Absent & Present & \\
\hline \multirow{9}{*}{ CBNRM } & \multirow{3}{*}{ Not Achieved } & Count & $5_{a}$ & $0_{\mathrm{b}}$ & 5 \\
\hline & & $\%$ within CBNRM & $100.0 \%$ & $0.0 \%$ & $100.0 \%$ \\
\hline & & $\%$ within conflict resolution & $83.3 \%$ & $0.0 \%$ & $23.8 \%$ \\
\hline & \multirow{3}{*}{$\begin{array}{l}\text { Partially } \\
\text { Achieved }\end{array}$} & Count & $1_{\mathrm{a}}$ & $4_{\mathrm{a}}$ & 5 \\
\hline & & $\%$ within CBNRM & $20.0 \%$ & $80.0 \%$ & $100.0 \%$ \\
\hline & & $\%$ within conflict resolution & $16.7 \%$ & $26.7 \%$ & $23.8 \%$ \\
\hline & \multirow{3}{*}{ Achieved } & Count & $0_{\mathrm{a}}$ & $11_{\mathrm{b}}$ & 11 \\
\hline & & $\%$ within CBNRM & $0.0 \%$ & $100.0 \%$ & $100.0 \%$ \\
\hline & & $\%$ within conflict resolution & $0.0 \%$ & $73.3 \%$ & $52.4 \%$ \\
\hline \multirow{3}{*}{\multicolumn{2}{|c|}{ Total }} & Count & 6 & 15 & 21 \\
\hline & & $\%$ within CBNRM & $28.6 \%$ & $71.4 \%$ & $100.0 \%$ \\
\hline & & $\%$ within conflict resolution & $100.0 \%$ & $100.0 \%$ & $100.0 \%$ \\
\hline
\end{tabular}

Each subscript letter denotes a subset of conflict resolution categories whose column proportions do not differ significantly from each other at the .05 level.

\begin{tabular}{|c|c|c|c|c|c|c|}
\hline \multicolumn{7}{|c|}{ Chi-Square Tests } \\
\hline & Value & Df & $\begin{array}{c}\text { Asymptotic } \\
\text { Significance } \\
\text { (2-sided) }\end{array}$ & $\begin{array}{l}\text { Exact Sig. } \\
\text { (2-sided) }\end{array}$ & $\begin{array}{c}\text { Exact Sig. } \\
\text { (1-sided) }\end{array}$ & $\begin{array}{c}\text { Point } \\
\text { Probability }\end{array}$ \\
\hline Pearson Chi-Square & $17.080^{\mathrm{a}}$ & 2 & .000 & .000 & & \\
\hline Likelihood Ratio & 20.123 & 2 & .000 & .000 & & \\
\hline Fisher's Exact Test & 15.515 & & & .000 & & \\
\hline $\begin{array}{l}\text { Linear-by-Linear } \\
\text { Association }\end{array}$ & $14.727^{\mathrm{b}}$ & 1 & .000 & .000 & .000 & .000 \\
\hline N of Valid Cases & 21 & & & & & \\
\hline
\end{tabular}

a. 5 cells $(83.3 \%)$ have expected count less than 5 . The minimum expected count is 1.43 .

b. The standardised statistic is 3.838 . 


\begin{tabular}{|c|c|c|c|c|c|}
\hline \multicolumn{6}{|c|}{ Cross-tabulation } \\
\hline & & & $\begin{array}{r}\text { Collec } \\
\text { Absent }\end{array}$ & $\begin{array}{l}\text { choice } \\
\text { Present }\end{array}$ & Total \\
\hline \multirow{12}{*}{ CBNRM } & & Count & $5_{\mathrm{a}}$ & $0_{\mathrm{b}}$ & 5 \\
\hline & Not Achieved & $\%$ within CBNRM & $100.0 \%$ & $0.0 \%$ & $100.0 \%$ \\
\hline & & $\%$ within collective choice & $83.3 \%$ & $0.0 \%$ & $23.8 \%$ \\
\hline & & Count & $1_{\mathrm{a}}$ & $4 a$ & 5 \\
\hline & Partially Achieved & $\%$ within CBNRM & $20.0 \%$ & $80.0 \%$ & $100.0 \%$ \\
\hline & & $\%$ within collective choice & $16.7 \%$ & $26.7 \%$ & $23.8 \%$ \\
\hline & \multirow{3}{*}{ Achieved } & Count & $0_{\mathrm{a}}$ & $11_{\mathrm{b}}$ & 11 \\
\hline & & $\%$ within CBNRM & $0.0 \%$ & $100.0 \%$ & $100.0 \%$ \\
\hline & & $\%$ within collective choice & $0.0 \%$ & $73.3 \%$ & $52.4 \%$ \\
\hline & \multirow{3}{*}{ Total } & Count & 6 & 15 & 21 \\
\hline & & $\%$ within CBNRM & $28.6 \%$ & $71.4 \%$ & $100.0 \%$ \\
\hline & & $\%$ within collective choice & $100.0 \%$ & $100.0 \%$ & $100.0 \%$ \\
\hline
\end{tabular}

Each subscript letter denotes a subset of collective choice categories whose column proportions do not differ significantly from each other at the .05 level.

\begin{tabular}{|c|c|c|c|c|c|c|}
\hline \multicolumn{7}{|c|}{ Chi-Square Tests } \\
\hline & Value & Df & $\begin{array}{c}\text { Asymptotic } \\
\text { Significance } \\
\text { (2-sided) }\end{array}$ & $\begin{array}{l}\text { Exact Sig. } \\
\text { (2-sided) }\end{array}$ & $\begin{array}{l}\text { Exact Sig. } \\
\text { (1-sided) }\end{array}$ & $\begin{array}{c}\text { Point } \\
\text { Probability }\end{array}$ \\
\hline Pearson Chi-Square & $17.080^{\mathrm{a}}$ & 2 & .000 & .000 & & \\
\hline Likelihood Ratio & 20.123 & 2 & .000 & .000 & & \\
\hline Fisher's Exact Test & 15.515 & & & .000 & & \\
\hline $\begin{array}{l}\text { Linear-by-Linear } \\
\text { Association }\end{array}$ & $14.727^{\mathrm{b}}$ & 1 & .000 & .000 & .000 & .000 \\
\hline $\mathbf{N}$ of Valid Cases & 21 & & & & & \\
\hline
\end{tabular}

a. 5 cells $(83.3 \%)$ have expected count less than 5 . The minimum expected count is 1.43 .

b. The standardised statistic is 3.838 . 


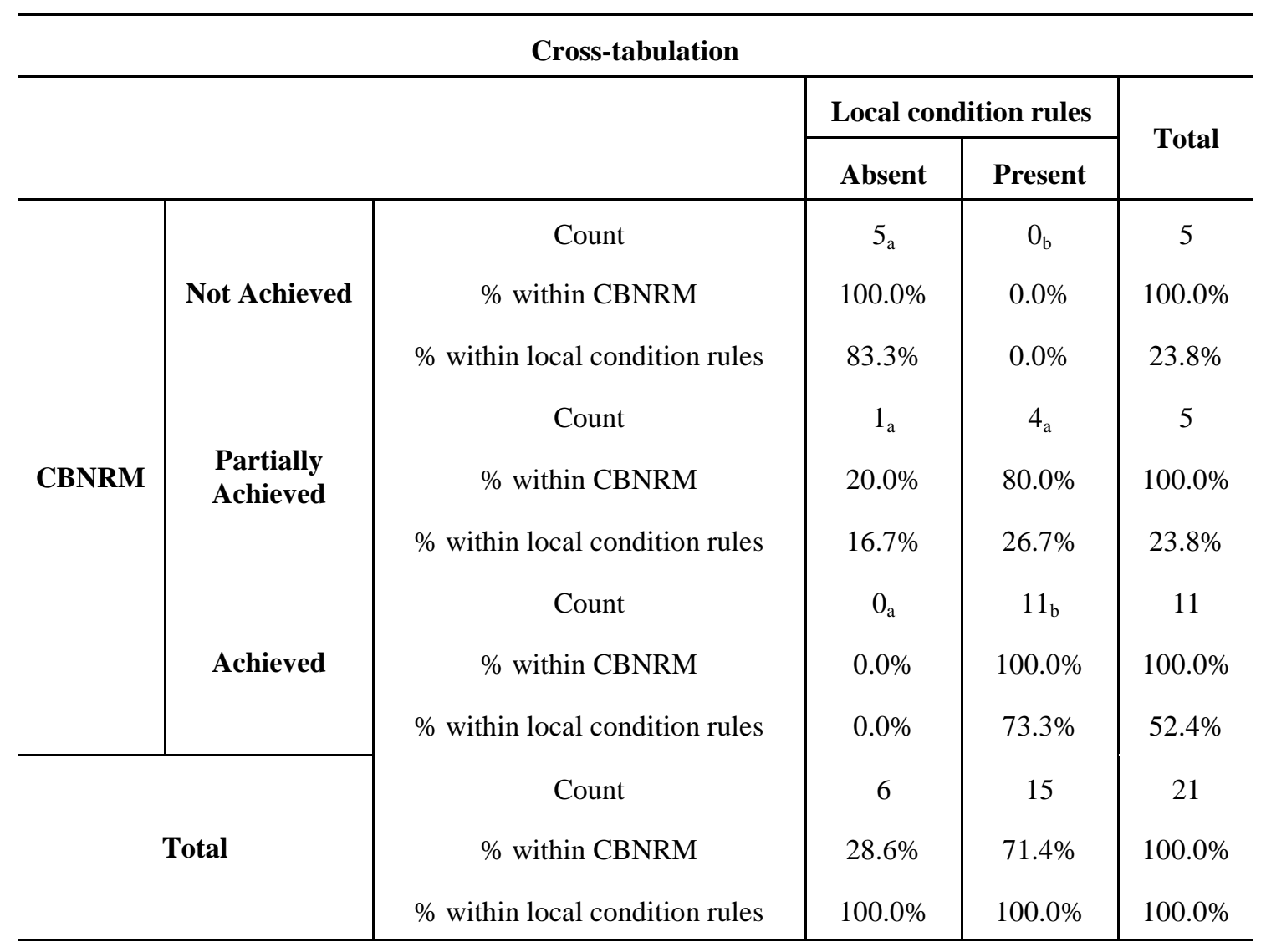

Each subscript letter denotes a subset of local condition rules categories whose column proportions do not differ significantly from each other at the .05 level.

\begin{tabular}{|c|c|c|c|c|c|c|}
\hline \multicolumn{7}{|c|}{ Chi-Square Tests } \\
\hline & Value & Df & $\begin{array}{c}\text { Asymptotic } \\
\text { Significance } \\
\text { (2-sided) }\end{array}$ & $\begin{array}{l}\text { Exact Sig. } \\
\text { (2-sided) }\end{array}$ & $\begin{array}{l}\text { Exact Sig. } \\
\text { (1-sided) }\end{array}$ & $\begin{array}{c}\text { Point } \\
\text { Probability }\end{array}$ \\
\hline Pearson Chi-Square & $17.080^{\mathrm{a}}$ & 2 & .000 & .000 & & \\
\hline Likelihood Ratio & 20.123 & 2 & .000 & .000 & & \\
\hline Fisher's Exact Test & 15.515 & & & .000 & & \\
\hline $\begin{array}{c}\text { Linear-by-Linear } \\
\text { Association }\end{array}$ & $14.727^{b}$ & 1 & .000 & .000 & .000 & .000 \\
\hline $\mathbf{N}$ of Valid Cases & 21 & & & & & \\
\hline
\end{tabular}

a. 5 cells $(83.3 \%)$ have expected count less than 5 . The minimum expected count is 1.43

b. The standardised statistic is 3.838 . 


\begin{tabular}{|c|c|c|c|c|c|}
\hline \multicolumn{6}{|c|}{ Cross-tabulation } \\
\hline & & & \multicolumn{2}{|c|}{ Sanction activities } & \multirow{2}{*}{ Total } \\
\hline & & & Absent & Present & \\
\hline \multirow{9}{*}{ CBNRM } & \multirow{4}{*}{$\begin{array}{c}\text { Not } \\
\text { Achieved }\end{array}$} & Count & $5 \mathrm{a}$ & $0_{\mathrm{b}}$ & 5 \\
\hline & & $\%$ within CBNRM & $100.0 \%$ & $0.0 \%$ & $100.0 \%$ \\
\hline & & $\%$ within sanction activities & $83.3 \%$ & $0.0 \%$ & $23.8 \%$ \\
\hline & & Count & $1_{\mathrm{a}}$ & $4 a$ & 5 \\
\hline & \multirow{2}{*}{$\begin{array}{l}\text { Partially } \\
\text { Achieved }\end{array}$} & $\%$ within CBNRM & $20.0 \%$ & $80.0 \%$ & $100.0 \%$ \\
\hline & & $\%$ within sanction activities & $16.7 \%$ & $26.7 \%$ & $23.8 \%$ \\
\hline & \multirow{3}{*}{ Achieved } & Count & $0_{\mathrm{a}}$ & $11_{\mathrm{b}}$ & 11 \\
\hline & & $\%$ within CBNRM & $0.0 \%$ & $100.0 \%$ & $100.0 \%$ \\
\hline & & $\%$ within sanction activities & $0.0 \%$ & $73.3 \%$ & $52.4 \%$ \\
\hline \multirow{3}{*}{\multicolumn{2}{|c|}{ Total }} & Count & 6 & 15 & 21 \\
\hline & & $\%$ within CBNRM & $28.6 \%$ & $71.4 \%$ & $100.0 \%$ \\
\hline & & $\%$ within sanction activities & $100.0 \%$ & $100.0 \%$ & $100.0 \%$ \\
\hline
\end{tabular}

Each subscript letter denotes a subset of sanction activities categories whose column proportions do not differ significantly from each other at the .05 level.

\section{Chi-Square Tests}

\begin{tabular}{|c|c|c|c|c|c|c|}
\hline & Value & Df & $\begin{array}{c}\text { Asymptotic } \\
\text { Significance } \\
\text { (2-sided) }\end{array}$ & $\begin{array}{l}\text { Exact Sig. (2- } \\
\text { sided) }\end{array}$ & $\begin{array}{l}\text { Exact Sig. (1- } \\
\text { sided) }\end{array}$ & $\begin{array}{c}\text { Point } \\
\text { Probability }\end{array}$ \\
\hline Pearson Chi-Square & $17.080^{\mathrm{a}}$ & 2 & .000 & .000 & & \\
\hline Likelihood Ratio & 20.123 & 2 & .000 & .000 & & \\
\hline Fisher's Exact Test & 15.515 & & & .000 & & \\
\hline $\begin{array}{l}\text { Linear-by-Linear } \\
\text { Association }\end{array}$ & $14.727^{\mathrm{b}}$ & 1 & .000 & .000 & .000 & .000 \\
\hline $\mathbf{N}$ of Valid Cases & 21 & & & & & \\
\hline
\end{tabular}

a. 5 cells $(83.3 \%)$ have expected count less than 5 . The minimum expected count is 1.43 .

b. The standardised statistic is 3.838 . 